\title{
Conflicting Treasures: contrasting resource use governance in two artisanal gemstone mining sites in Madagascar
}

\author{
Merrill S.A. Baker-Médard ${ }^{1}$ \\ University of California, Berkeley
}

\section{Introduction}

It was a hot afternoon in Northern Madagascar and I was harvesting rice in a field with a group of women as Maman'So ${ }^{2}$ recounted a story to the rest of us. She was laughing as she described that earlier in the day she had seen several gemstone miners walking into the nearby protected area and in passing a cairn that marked the boundary, climbed atop the cairn and excreted all over it. She exclaimed, "They are not scared of anything!" We chuckled to ourselves for a few moments and I remembered one of the boundary markers I saw earlier in the week near the tourist entrance of the state managed protected area. The cairns in the area are large vertical cement and stone formations, about chin high, that boldly mark the open grassy fields that one must walk through to enter the forested hills and canyons of the protected area. Then I saw Maman'So's face grow more solemn and she said "But they do not follow custom, they dig for gemstones in sacred ground." The miners to whom she was referring were recent Malagasy migrants to an area adjacent to a protected area established in the 1950s by the French colonial government, and a place where her family had lived for generations. Over the next few months I learned that since the arrival of gemstone mining in the area, tension between gemstone mining and biodiversity conservation efforts had escalated at times into violent armed conflict and several miners and policemen had died as a result.

The violence and tension due to the gemstone mining adjacent to this colonially established protected area differed markedly from another mining site I visited a few months later located next to a communitymanaged protected area. While gemstone mining also took place inside the community-managed protected area, villagers had established a system of rents and concessions that they demanded migrant miners follow. Astonishingly, these requests were followed. Additionally, local taboos were largely obeyed and sacred sites were not mined.

Using an in-depth comparative method, this research set out to understanding some of the dynamics that influenced how and possible reasons why local control over resources differed between these two sites. The importance of the adjacent protected area emerged in interviews concerning people's claims to natural resources, thus highlighting differences between state-managed versus community-managed conservation.

Gemstone mining sites in Madagascar adjacent to conservation areas are particularly interesting locations for exploring property relations. How resource governance occurs and who is involved in the decision making and enforcement processes are subject to the dispersion of power across scales and actors. This research picks up on Foucault's notion of governmentality by focusing on the way in which both de facto and de jure property claims play out in each mining site. Specifically I examine how the discourse and practices of people and organizations working in conservation influence the way in which communities govern themselves and their resources. I look at how resource claims are exercised, by whom, and by what means in two artisanal gemstone mining sites in Madagascar. The extreme opportunity and disturbance that occurs in an area due to the arrival of artisanal gemstone mining provide a useful context in which to analyze what property claims emerge as new modes of resource use dominate a landscape. I argue that conservation practices and discourse influence the way some communities organize themselves to reap benefit from, and decrease detriment caused, by gemstone mining. As a corollary, I posit that the way in which people organize, or fail to organize, in order to reap benefit from gemstone mining relates to historical conservation practices and discourses, in other words, the historical production of place that interweaves 'the local', with 'the national' and 'international'. This research also contributes to debates in the community based natural resource management (CBNRM) literature by examining some of the unintended consequences of decentralized management discourse and practices on a community's claims to mineral resources.

\footnotetext{
${ }^{1}$ Merrill S.A. Baker-Médard, PhD student, Department of Environmental Science, Policy and Management, University of California, Berkeley, CA, USA. mezbaker "at" berkeley.edu. This research would not have been possible without the help and guidance in the field of Charlotte Lahiko Nagnisaha, Miza Pierrette Razafindravelo, and Floris Saula. I would also like to extend my deep gratitude to Louise Fortmann, Ernie Alleva, Gill Hart, Leo Arriola, Nancy Peluso, Esther Conrad, Myron Baker and two anonymous reviewers for their invaluable critiques and suggestions. This research was supported by a NSF Graduate Research Fellowship. Initial aspects of this research were also supported by the Rufford Small Grant Foundation and a grant to the University of Vermont from the Tiffany \& Co. Foundation (PI: Saleem H. Ali, with assistance from Laura Tilghman, PhD student, Department of Anthropology, University of Georgia). All errors and shortcomings remain my own.

2 All personal and village names are pseudonyms except for Ambondromifehy and Ankarana, which exist in related published works.
} 
Many gemstone mining sites are volatile. This is in part due to the boom and bust cycle of artisanal gemstone mining, but also because of the lucrative nature of the industry. They are places where jealousy, sabotage, and physical violence occur in association with large cash transactions and gem trading. In the mining sites adjacent to state-managed protected areas, I witnessed heated conflict and instances of violence between park authorities and gemstone miners. Only two weeks before I arrived in one mining site there had been a shooting of two miners by military personnel hired by the protected area authorities. In one village adjacent to a state-managed protected area, numerous local people complained about disrespectful migrant gemstone miners digging in their fields. In a village adjacent to a community-managed protected area, people living in the area long before gemstone miners came were able not only to keep migrant miners out of their fields, but also out of large parts of the adjacent community-managed protected area. However, what was perhaps most astonishing in the gemstone mining site adjacent to the community-managed protected area was that migrant miners "rented" areas to dig mining pits and even paid concessions to de facto land-owners, up to $10 \%$ for some of the large gems. Villagers organized themselves to divide land in the area, extract rents from the mining population, and established a degree of spatial control protecting their sacred places. The villagers located adjacent to the state-managed protected area, by contrast, did not organize themselves in the same way, and as a result were not able to exert the same amount of control of the resources around their communities.

Hundreds of gemstone mining sites of various sizes exist throughout Madagascar, six of which I visited from 2004-2008, spending only a few days in some while spending several months in others. This research project focuses on the two gemstone mining sites where I spent the most time. I visited both sites repeatedly over the five year period, staying a total of four months in each site. These two sites were initially chosen not with regards to the conservation strategies endorsed in their adjacent protected areas, but because they were sites with personal contacts and, therefore, more secure to revisit periodically and conduct research for an extended period of time. It was only after conducting research more generally on gemstone mining extraction in these areas that differences in the way people talked about and acted in relation to adjacent protected areas became clearer. Research primarily relied on semi-structured interviews, participant observation and oral histories.

The article proceeds in three sections. In the first section, I outline the context of gemstone mining and conservation in Madagascar. In section two, I discuss theoretical debates within the CBNRM literature and how they relate to community conservation in Madagascar. Additionally, I use Foucault's notion of governmentality to frame the way in which conservation regimes influence claims to authority over natural resources. In the last section, I will use two case studies to show how conservation discourse and practices, particularly the legitimization process tied to establishing protected areas in each case, transform the way in which people conceive and act upon their rights as resource owners and managers in gemstone mining sites.

\section{Background}

Madagascar has seen a rapid expansion of both conservation areas and gemstone mining in the past decade. The island globally renowned for its biodiversity, species endemism, and high species extinction rates (Myers et al. 2000), recently committed itself to a threefold increase (6 million hectares) in protected areas under a plan called the Durban Vision (Kremen et al. 2008). Several years before the political crisis that started in 2009, Madagascar saw a dramatic expansion in artisanal gemstone mining, ${ }^{3}$ an industry that was touted by USAID and the World Bank as critical to Madagascar's economic development (Duffy 2007). With the opposing pressures for biodiversity conservation and gemstone extraction on the same land, communities at this interface have responded very differently in terms of their participation in, ability to profit from, and capacity to prohibit or control nearby resource extraction (Duffy 2007; Walsh 2003). In Madagascar, gemstone mining is illegal inside protected areas (including state protected areas and federally recognized community-based natural resource management areas) and within buffer zones up to several kilometers around a protected area (Code Minier 2005).

Many gemstone miners in Madagascar are migrants, ${ }^{4}$ often travelling from one mining site to the next, staying in an area a few weeks up to many months, and occasionally staying permanently in a place even after mining stops. While Malagasy men trade most of the larger, individually-sold stones primarily to foreign buyers $^{5}$ who set up shop in larger mining towns and regional commercial centers, some of the smallest stones

\footnotetext{
3 "Artisanal" refers to small-scale mining operations, that are generally loosely organized under cooperative arrangements, and that rely on hand tools and manual labor. There are an estimated 13 million artisanal miners across 30 developing countries (CASM, www.artisanalmining.org).

${ }^{4}$ It is often the case that the pre-mining population also engages in gemstone mining and it should be noted that artisanal gemstone mining is conducted by Malagasy in Madagascar. The term "migrant" refers to intra-national migration.

These are primarily Thai, Sri Lankan and Pakistani, but also include Indian, Guinean, Senegalese, Congolese, French, Swiss, and others.
} 
are sold together by weight by women to Malagasy traders or foreign buyers. At a given trading site, one may see a large painted cement building housing a Sri Lankan gemstone trader, in front of which one may find a cluster of Malagasy middle-men traders clutching small white trays and narrow-beam flashlights. To the side of the building one may find a group of women also waiting with small white trays and small copper balances to weigh smaller stones (Figure 1, 2). Adjacent to the women buyers, one may find a group of small children sifting through the dirt and dust for dropped gemstones, putting small rocks and stones into their mouth to clean off the dust in hopes of finding a shiny colored gem.

There is little incentive for miners to mine legally in Madagascar. Not only can it be expensive for a small-scale gemstone miner to purchase a prospecting and then trading permit, but it is also difficult to navigate the complex and distant bureaucracy. And there are many areas for which permits are not granted including in and adjacent to all nationally recognized (whether officially decreed on in the process of being decreed) protected areas. Many gemstone mining sites are located in or around protected areas which were established prior to the arrival of gemstone mining to the island in the mid 1990s. No gemstone exploration or exploitation permits are granted in conservation areas or up to two kilometers around these protected areas. Thus, conflict pertaining to gemstone mining in and around protected areas is expected to increase progressively as their number and size increase (Cardiff and Andriamanalina 2007).

Colonial land appropriation, whether for immediate extractive use, delayed extractive use, or the preservation of nature, is an important historical legacy contributing to some people's distrust of statemanaged protected areas. The Water and Forest Service, created within the first year of colonial administrative occupation (1895-1960), aimed to protect forests for "rational economic exploitation" (Kull 2004). Large tracts of forested land were distributed as logging concessions to both colonial companies and individuals (Brown 2002; Desjeux 1979; Kull 2004; Thompson and Adloff 1965). A suspected three quarters of the primary rainforest existing at the start of colonization was destroyed in the first 30 years of colonial rule, some, if not most of which was due to colonially controlled or contracted extraction (Fanon 1963; Kull 1996; Mutibwa 1974). Thus, while local people were barred from resource use in some areas, colonizers benefited from unregulated resource extraction in other areas, often with the use of forced Malagasy labor (Sodikoff 2005).

While the majority of land appropriated by the colonial government was granted as forest and agriculture concessions (Gouvernement Général de Madagascar et Dépendances 1937, 1937; Jarosz 1993) some of the land appropriated during colonization was used for the preservation of nature, which enabled Madagascar to be one of the first French colonies world-wide to establish a network of protected areas. These colonially established protected areas still comprise a substantial proportion of Madagascar's current protected area network (Goodman and Benstead 2003). The colonizer's methods of land appropriation, often dispossessing locals of their communal and private land, as well as their forceful protected area management strategies, were similar in areas used for colonial extraction and areas managed to preserve the island's unique flora and fauna (Gezon 2006; Jarosz 1993; Kull 2004; Sodikoff 2005). The similar methods of land appropriation, despite the purportedly different rationale underpinning the establishment of different protected areas, probably contributed to a general uncertainty amongst locals concerning the real goals of protected areas. Local people's experience with how, and perception of why, Malagasy land was enclosed in protected areas is important in understanding the two case studies.

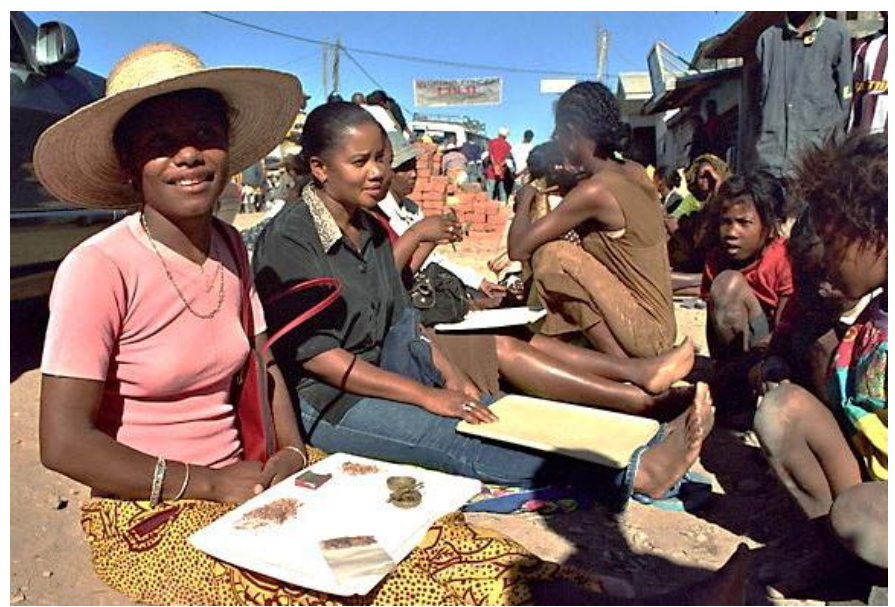

Figure 1: Women small-stone buyers in a Madagascar gemstone trading hub.

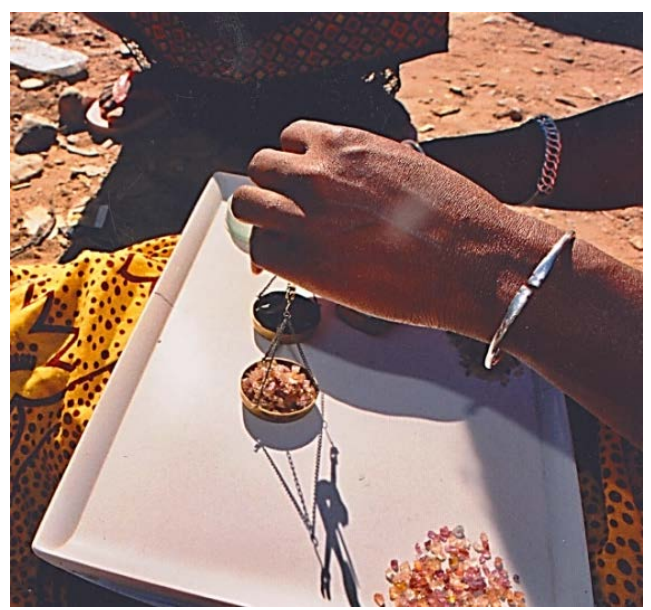

Figure 2: The smallest and lowest quality gemstones are often sold by weight. 
Shortly after independence in 1960 the Malagasy government, in conjunction with several global conservation organizations, established new protected areas in Madagascar. Despite the new postindependence administration, the command and control strategy of protected area management initiated by the colonial administration remained intact, and was endorsed by the newly independent government. The lack of divergence between the colonial and post-colonial order was a common phenomenon for many post-colonial, primarily urban, political parties who maintained close ties with colonizers and alliances more generally (Cooper 1998; Fanon 1963). These close ties, often in the form of French conservation and/or development advisors to the Malagasy government, helped to recreate colonial resource governance practices in Madagascar. In 1963, three years after Malagasy independence, the World Wildlife Fund (WWF) began working in Madagascar. Six years after independence, USAID and Cooperation Suisse began their bi-lateral aid programs aimed specifically at assisting development and environmental conservation (Kull 1996). Although the colonial administration had officially resigned de jure control over the state, a strong foreign presence remained in conducting conservation and development projects.

Since independence, and most notably since the late 1980s, an enormous amount of bi-lateral and multi-lateral aid has entered Madagascar for the protection of its unique biodiversity. In the early 1990s, shortly after Myers (1988) published his influential "hotspot" paper, and much in line with the general scientific consensus at the time, Madagascar gained status as an international conservation priority and experienced an exponential increase in the amount of bilateral and multilateral funding for conservation (Kull 1996). By 2000, Madagascar was listed as a "super priority" for conservation globally (Myers et al. 2000) and in 2003 at the $5^{\text {th }}$ World Parks Congress in Durban, South Africa, the president of Madagascar vowed to triple the amount of protected area in Madagascar, a commitment dubbed the "Durban Vision." This initiative brought an additional US\$50 million to Madagascar for conservation but raised the challenge of how conservation would be carried out on such a large scale (Norris 2006). Therefore, accompanying the Durban Vision was legislation that broadened the definition of protected areas to include new categories of protected area: Natural Parks (IUCN category II), Natural Monuments (IUCN category III), Protected Landscapes (IUCN category V), and Natural Resource Reserves (IUCN category VI) (Norris 2006). This new legislation encouraged organizations other than governmental agencies to manage protected areas, including the private sector and non-governmental organizations. Staying with the old model of state-centered protected area management would not be financially or bureaucratically feasible with the scale of proposed protected area expansion, therefore decentralized management and a reliance on community involvement was initially touted as a way forward with the protected area expansion (Durbin 2006; Fritz-Vietta et al. 2011; Pollini 2011). However, the initial intention to decentralize management and to prioritize community involvement was quickly reduced to mere rhetoric, and decisions concerning protected area location and rules were concentrated in the hands of primarily non-state actors including private entities and NGOs (Corson 2011a, 2011b; Pollini 2011).

\section{Community-based management and resource governance}

The use of the term "community-based natural resource management," although a longstanding local practice in many areas of the world, emerged with vigor in international conservation and development discourse in the early 1990s (Brosius, Tsing, and Zerner 2005). Shortly after the 1992 Earth Summit in Rio, decentralized natural resource governance, which called for greater community participation, emerged as an alternative to top-down or "fortress" style conservation strategies (Adams and McShane 1992; Baland and Platteau 1996), and took hold in Madagascar (Sodikoff 2007). In theory, CBNRM is a resource management strategy that devolves decision-making authority to local people. It is a "rural development paradigm that combines biological conservation and sustainable use of natural resources" recognizing that "villagers have sophisticated knowledge of local ecological and social conditions that can be effectively used to manage natural resources" (Getz et al. 1999). Although there is a great variety of CBNRM configurations, most adhere to some level of decentralized management that operates to varying degrees through the local communities themselves. According to some authors, a shift from a strongly top-down and fortress-style conservation to a more bottom-up and community-focused strategy is due to several global phenomena including the indigenous people's movement, an increasing number of "failed conservation" cases world-wide, and continued resistance from excluded people living in and around protected areas. Research on fortress style conservation has certainly revealed a variety of these problems (Adams and Hulme 2001; Brockington 2002; Brockington, Duffy, and Igoe 2008).

CBNRM proponents posit that the misuse of resources (or overexploitation) will be significantly curtailed if local communities partake in resource management. This follows a related argument that community resource management will help prevent the ill-will and potentially environmentally destructive protests associated with people being displaced from other types of conservation areas (Campbell 2002; Western, Wright, and Strum 1994). The normative foundation underlying CBNRM in this context is that local people will partake in environmental management when the benefits are perceived to exceed the costs 
(Murphree 1993, 2009), and when committed to natural resource management, they are more efficient managers because of their intimate knowledge of their environment (Shrader-Frechette and McCoy 1995).

Despite its popularity, CBNRM has been sharply criticized. One line of criticism concerns the fact that communities are not necessarily harmonious and homogenous, arguing instead that they are often contentious groupings in which access and wealth are distributed unevenly (Agrawal and Gibson 2001; Leach, Mearns, and Scoones 1999; Li 2002; Peluso 1996; Tsing 1999). Within a given "community," ethnicity and class directly influence access to and control over property and even within a household, women's access to and use of resources is often different from that of men (Agrawal and Gibson 1999; Fortmann, Antinori, and Nabane 1997; Massey 1994). Another line of criticism of CBNRM relates to legitimacy, or the ability to truly enfranchise local populations in resource management (Agrawal and Gibson 1999; Ribot 1999). CBNRM is seen as mere new and glossy rhetoric that fundamentally fails to shift the terms on which power is negotiated between state, non-governmental organizations, and resource users (Borrini-Feyerabend and Tarnowski 2005; Sivaramakrishnan 2000). This line of argument asserts that while local communities might have varying degrees of de jure control over resources, in many cases de facto power remains in the hands of the government and non-governmental organizations (Campbell and Vainio-Matila 2003; Murphree 2009).

Although a number of authors believe one should not throw the participatory conservation baby out with its dirty bathwater (Madzudzo, HaBarad, and Matose 2006), conservation strategies in some areas have moved back towards fortress style protected areas controlled by a centralized entity, as seen in the rise of private parks, and increasing support for "shoot-on-sight" policies for illegal resource use (e.g. hunting elephants for ivory) within a protected area (Brockington, Duffy, and Igoe 2008; Messer 2010; Terborgh 2000).

While some authors indicate that the pendulum swinging away from community centered conservation also applies to Madagascar (Corson 2011a; Pollini 2011) at least one paper shows many new communitybased conservation projects have been initiated since the Durban Vision in 2003 (REBIOMA 2012). However, CBNRM as a conservation strategy did not arrive in Madagascar with the Durban Vision initiative. Gelose (Gestion Locale Securisée, or secure local management) emerged as a state-endorsed conservation strategy in the late 1990s (Kull 2002; Pollini and Lassoie 2011). Gelose was espoused as a sociallycompatible conservation strategy where rules and regulations concerning resource use would automatically be legitimized by their placement into the traditional process of rule-making (Rakotoson and Tanner 2006). As expected given the critiques of CBNRM outlined above, these previous iterations as well as more current versions of CBNRM initiatives in Madagascar have largely been advanced by, and for the objectives of, foreign environmental NGOs (Dressler et al. 2010; Pollini and Lassoie 2011).

Although the powerful ideals of CBNRM have largely failed to materialize (Dressler et al. 2010) the variety of goals and interests attached to a CBNRM project, despite potential tensions, identify CBNRM as a flexible process. While CBNRM projects are "sold" at the national level in Madagascar as a low-budget way to expand biodiversity conservation objectives on the island, at the local level NGO and government representatives interfacing with "partner communities" sell the idea of CBNRM to local people very differently. By observing several dozen community-NGO partner meetings in one case study area, I have seen NGO as well as governmental organization representatives use arguments that stem directly from the powerful ideals with which CBNRM gained widespread popularity, asserting that communities involved in CBNRM projects will be the decision makers as well as primary beneficiaries of the project. In the process, community-based committees are formed, rules are codified, and papers are signed. Although these actions could be seen as a vacuous attempt to advance the needs and rights of a largely disenfranchised group, these processes alter social relations. While some authors have focused on the intra-community divisiveness engendered by the establishment of a CBNRM project (Agrawal and Gibson 1999; Fortmann, Antinori, and Nabane 1997; Massey 1994), this article sheds light on the way in which the discourse associated with CBNRM might be taken up and used by villagers to govern resources in unexpected ways. Communityconservation initiatives are yet one of the many ways in which boundaries, both the physical and social in a given "community" shift as shared identity, employment, and association change over time (Fortmann and Roe 1993; Sodikoff 2009).

People use their relationship to a CBNRM project in different ways. Just as an NGO involved with a conservation project might publish photos and write about the project in pamphlets and reports to garner more funding, local committee members involved in a CBNRM project might incite their authority as resource managers to shape other's access to natural resources in an area. If we look at the establishment of a conservation project as a process, stemming from the particular positions and objectives of the participants in this process, we should not only focus on the power relations that are inward facing, involving people and power dynamics of those "participating" in the project, but also the outward facing relations. In the cases explored here I focus on the relationship between communities "receiving" conservation intervention, and an incoming migrant mining population. I draw on Foucault's definition of governmentality to clarify how power is dispersed across multiple scales and actors. Foucault identifies governmentality as "the ensemble 
formed by the institutions, procedures, analyses and reflections, the calculations and tactics that allow the exercise of this very specific albeit complex form of power, which has as its target population, as its principal form of knowledge political economy, and as its essential technical means, apparatuses of security" (Burchell, Miller, and Gordon 1991). Foucault's description of governmentality, albeit a dense one, helps highlight that governance has directionality, and most likely multiple directions pushed by multiple actors. The "calculations" and "tactics" of one group/process enables power to be exercised in relation to a "target population." Arun Agrawal builds on Foucualt's notion of governmentality in terms of environmental governance, and coins the term "environmentality." Environmentality, Agrawal advances, is an "approach to studying environmental politics that take seriously the conceptual building blocks of power/knowledge, institutions, and subjectivities" (Agrawal 2005: 8).

In Madagascar, the concept of environmentality helps draw attention to the multitude of actors, motivations, and processes that determine how conservation unfolds in a particular place, and consequentially how "partnerships" are produced without necessarily the alignment of goals (Hanson 2007). Governance of natural resources in Madagascar is layered with local, national and international agendas each with their accompanying discourse. Institutional regimes of environmental regulation, whether conforming to a statemanaged or community-managed model, influence how people understand and relate to their environment (Agrawal 2005). However, as Agrawal cautions, institutionalized motivations and calculations that work to influence a particular individual's relationship to his/her environment are not necessarily the ones an individual enacts. The agenda of any given conservation intervention is invariably transformed by local people's interpretation of and relation to the intervention in their particular context.

Analyzing the way in which the discourse and practices of environmental governance regimes are interpreted and utilized by communities concerning resource use authority is the heart of this research. The cases below outline the ways in which particular actors assert their claims to natural resources in and around gemstone mining sites, and what discourses they draw on to legitimize their claims.

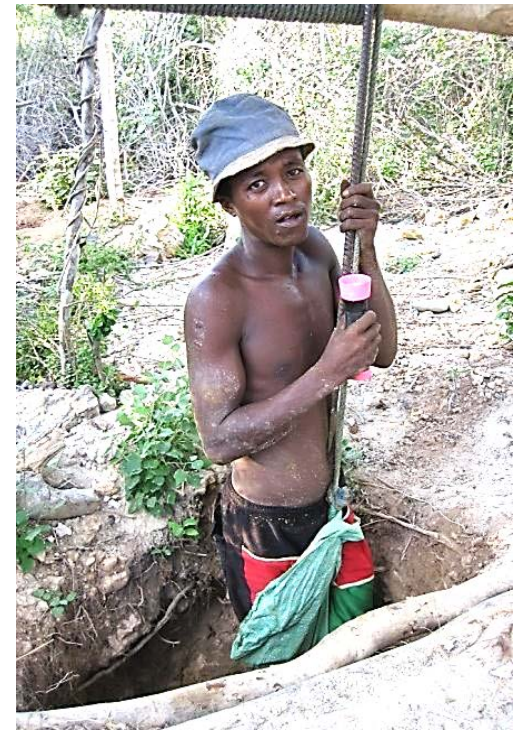

Figure 3: Miner being lowered into a hole in Soabiby

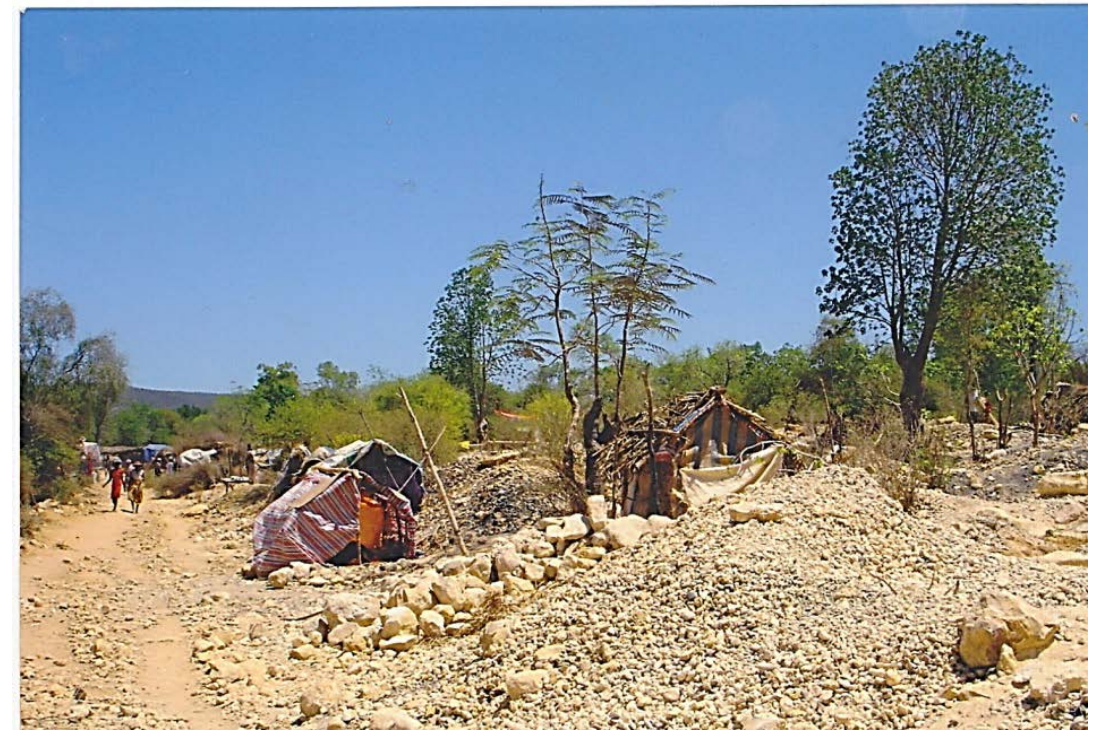

Figure 4: Mining camp amidst mounds of extracted soil in southern Madagascar

\section{Case studies}

Instead of assuming the dichotomy between CBNRM and top-down fortress conservation, this article attempts to show how conservation strategies are carried out in a particular "place," that is deeply influenced by its particular social, environmental, and political-economic history. The two case studies are by no means intended to be representative cases of CBNRM or state-managed protected areas globally. Instead, methods of relational comparison are used, which Gillian Hart explains as "grounded in an understanding of place not as a bounded unit, but as always formed through relations and connections with dynamics at play in other places, and in wider regional, national, and transnational arenas" (Hart 2002). 
In this section I explore the way in which conservation practices and rhetoric have influenced both the way in which people understand as well as act upon their property rights in two mining sites. The first case focuses on Ambondromifehy, located in northern Madagascar adjacent to a state-managed protected area. The second case focuses on Soabiby, located in southern Madagascar adjacent to a community-managed protected area. Both cases examine the relationship between people living in an area prior to the arrival of gemstone mining and people who migrate to an area in pursuit of gemstones. This relationship is then analyzed in conjunction with the history of conservation discourse and practice associated with each case. At the end of this section I outline alternative explanations that could be contributing to the differences observed in each site concerning property relations.

\section{1) Sapphires and state management: the case of Ambondromifehy}

Ankarana Special Reserve (hereafter Ankarana), located in Northern Madagascar, is a protected area that was set up by the colonial government in 1956 and is currently managed by Madagascar's national park service. Most resource extraction is deemed illegal within the confines of the protected area which is patrolled by park staff. More recently, gemstone mining occurred illegally inside the protected area, and to the dismay of residents in a village adjacent to Ankarana, also occurred in agricultural fields and sacred sites. While attempts were made, for the most part local residents were unable to exert much control over where or the way in which gemstone mining occurred in the area. The park service was unable to effectively prevent gemstone mining within the park and the park itself acted more as an attractant than a deterrent to gemstone miners, for reasons discussed below.

In the Ankarana region, men, and to a smaller extent women, have the right to own agricultural land based on historical family ties or purchases(Gezon 2006). Even without an official title, de facto land-rights are recognized locally(Gezon 1997). Forested or wooded land outside a protected area is frequently seen as common property. When the colonial government established Ankarana, the community's commonly-held property, and even land that had been managed by clearing and with the use of fire, was appropriated by the government and included within the protected area boundaries. As a result, many people living adjacent to Ankarana opposed the delineation of the protected area's boundaries. According to the director of the Ankarana Special Reserve, until 1995 the most common reasons people transgressed protected area boundaries were for the extraction of timber for construction, wood for charcoal, as well as the harvest of certain plant species for local consumption (personal communication, September 20, 2004). Ankarana employees who interact regularly with residents living adjacent to the protected area had strong narratives about the local recalcitrant and unmotivated people who are generally unwilling to partake in the conservation efforts of the protected area.

In 1995 sapphires were found just outside the northeast portion of Ankarana near a village called Ambondromifehy. Ambondromifehy was first established by farmers in the early 1900s and by 1995 had a population of approximately 400 people. With the discovery of sapphires, within just a few years Ambondromifehy grew from about 400 to approximately 14,000 people (Walsh 2005, 2006) (Walsh 2003, 2005). Ambondromifehy was the first gemstone mining site in Madagascar where miners could access gems in alluvial deposits (stream beds), which meant that with hand held tools and pulley systems, nearly anyone could mine them. Many people with no previous experience partook in the frenzied search for the valuable sapphires. People came to Ambondromifehy by the thousands, primarily young men but also women, older men, and children. Whole families helped dig small pit mines and sort through the earth and rocks. Due to their size and agility young boys were often sent down into the narrower and deeper holes.

Ankarana protected area rules were contravened most frequently in 1996 and 1997 (Ankarana Special Reserve Director, personal communication, June 10, 2004); therefore, in 1998 the government decided to take control of guarding the protected area's boundaries with the national police(Walsh 2003, 2005). All environmental organizations in the region were extremely concerned about the negative impact gemstone mining had on the unique and fragile biodiversity within Ankarana's borders.

Miners interviewed in 2004 knew that mining within protected area limits was illegal, yet openly acknowledged that they did so regardless. One day when accompanying a group of miners to their mining site, I passed a protected area boundary marker. A yellow and green sign erected by the protected area staff read Ala Fady, literally "Taboo Forest," yet was crossed out with charcoal and under it was written miala colon or "go away colonizer." One of the miners read it aloud and the group laughed as they passed it walking into the forest. Ankarana was established by the French but is currently run by the Malagasy staffed parastatal, Madagascar National Parks. Despite this, the crisscrossing of time and space on this one sign was strikingly clear. This sign was similar to the brazen act of excreting on a boundary marker. When gemstone miners entered the protected area, it was not merely to extract resources, but was also showing defiance against a particular resource governance regime. The legitimacy of this regime, potentially seen as foreignoperated or perhaps an extension of a particular colonial objective, was contested by transgressing the protected area boundaries. 
The complex socio-political and historical relations at play help to highlight the identity of place, which Massey asserts "does not derive from some internalized history" but rather "from the specificity of its interactions with 'the outside."'(Massey 1994) Boundaries are ongoing expressions of political processes. What Ankarana means, or how it is understood as a "place," changes as the social, political and environmental relations change around it. Ankarana's boundaries, despite the fact that they were established over 50 years ago, represent a type of ongoing colonization for some miners. This is compounded by the fact that although some of the actors have changed in terms of who governs the park, a similar dynamic between resource users and conservationists remains in Ankarana.

As Walsh (2005) points out, some of those involved in the gemstone mining trade near Ankarana do not hesitate to recall its colonial history in order to challenge the very reason for establishing the protected area. Walsh emphasizes how some involved in the gemstone mining trade believe that "the French have always known about the value of what could be found in this place, and this is why they set it aside while they could" (p659) and goes on to explain that "One trader even described the caves at the center of the reserve as one of France's "safes" (coffres), something into which the former colonial ruler could dip occasionally if in need of a little extra cash." Much in line with this deep suspicion of foreign interests and intents, the Malagasy government and their part in the continued protection of Ankarana was not immune from criticism. Many miners interviewed also condemned the government as part of the protected area conspiracy. Walsh highlights this point, observing that numerous artisanal miners in the Ankarana region were suspicious of the motives that conservationist's had to keep "the park safe from the incursions of Malagasy miners [which] has been supported by politicians and a national police force that are widely believed to be corrupt..." (Walsh 2004) One report claims an estimated $90 \%$ of the people in the mining sector in Madagascar, "especially those in authority," are corrupt to some degree(Economist 2005). The miners interviewed heard about and directly observed corruption from the highest levels of government down to local officials and state military forces. People living in and around mining sites experience first-hand how people with access to institutional power wield it to legitimize natural resource appropriation, and/or collect bribes.

Much in line with these observations, a common justification I heard from miners for entering the protected area was that the sapphires were better quality and closer to the surface inside it. This argument was a common thread in many interviews and conversations, and could be deemed the "jackpot effect." The idea of a jackpot relates to many miners' belief that governmentally-managed conservation areas have been established to withhold prime land with lucrative or coveted resources from the Malagasy population for the benefit of the governmental officials or their friends. While there is not enough evidence to say whether the mere presence of a state-managed protected area attracts miners, it is clear that once gems are found, the protected area itself has an alluring effect. In interviews, the protected area was mentioned by many as one of the more dangerous but "best" spots.

The "jackpot" narrative, which seemed like a conspiracy theory at first, was contextualized in terms of colonialism and current day conservation discourse and practices. It is not difficult to see how it could become powerful enough to the point that many gemstone miners had little hesitation transgressing national law, even if it put them in danger of being arrested or even killed. The pervasive corruption in the mining sector helps their argument. The spatial representation of colonial domination embodied by the protected area, as well as the fortress style conservation practices perpetuated by current conservation managers (such as military patrolled borders and the threat of fines, jail-time or even death), reveals the importance of history in explaining current patterns of resource use and control in Ambondromifehy. The "instinct" the gemstone miners were following by going into Ankarana could be seen as an expression of Massey's (1994) dynamic conception of place, where Ankarana is co-constituted by historical as well as current social practices that are imbued with ongoing and shifting power relations.

\section{Taboos versus tunneling}

Despite frequent incursion into this state-protected area, there was nonetheless a great number of mining tunnels (narrow pits dug into the earth) that took place outside the protected area boundaries, within the de facto common and private property of communities surrounding the protected area.

According to some village elders and numerous miners who had been in Ambondromifehy since the discovery of gemstones, the first miners followed the norms and customary practices of the region and introduced themselves to the village heads who tend to be elders or tompontanana(Walsh 2003). Also corresponding with Malagasy custom, these newly arriving migrant miners asked what local customs and taboos they should respect, and assured the village leaders that they would behave respectfully while in the region. According to one tompontanana in Ambondromifehy who was interviewed in 2006, as rumors of the presence of sapphires in the region spread and tens of migrant miners turned into hundreds and then thousands, his as well as other tompontanana's authority over the incoming population waned. After a short time, many miners did not request permission to prospect or construct houses in the vicinity of Ambondromifehy(Walsh 2003). Migrant miners set up small grass and twig sleeping huts in any flat area 
they could find, including between people's rice fields and on communal cattle grazing land. Individual land owners periodically asserted their claims on the land and desires for people to move, yet these wishes were not always honored and occasionally caused verbal and physical conflict between the newcomers and the premining tenants. Over the years, some migrant miners stayed, the population of Ambondromifehy shrank from 14,000 to several thousand, and small straw sleeping huts were built into more permanent structures (enlarged and constructed with bamboo or corrugated tin walls and palm roofs) and new sets of social relations revolving around gemstone mining and trading emerged(Walsh 2002).

During one visit to Ambondromifehy in 2004, it was clear that most migrant miners did not know the customs and social practices of the local inhabitants. Others who knew certain customs and land taboos in the area would obey some (such as offering rum to ancestors inhabiting a sacred tree) but disobeyed others (such as cutting down a sacred tree near the village). Migrant miners built houses and dug tunnels and mining pits in and around sacred sites, bathed and washed stones in prohibited parts of the river, left abandoned houses which became pest and fire hazards, and dug on taboo days (Tuesdays), all of which are deemed deeply disrespectful (Ambondromifehy village elder, personal communication, April 8, 2004) (Walsh 2003). Some of the tompontanana of Ambondromifehy attempted to approach miners if they broke a local rule or disrespected a sacred site. Unfortunately, the compensation requested (such as paying an individual for damage done to his/her property, or washing a defaced sacred site with cow's blood) was seldom fulfilled. While the Ambondromifehy residents were not upset at the arrival of gemstone mining to the area per se, they were troubled by the migrant miners' general disregard for certain local customs as well as tompontanana authority. What renders the situation more complex, however, is the fact that many villagers who lived in the area prior to the mining boom became gemstone miners themselves, including some tompontanana. Furthermore, some tompontanana dug for gems in places deemed sacred. Walsh (2006) helps illuminate what seems to be at the crux of this paradox arguing that when one looks closely at context, actions that seem contradictory may be in fact be the most coherent line of action given the alternatives. Alternatives might include standing up to an enormous number of migrant miners, calling on park guards who are theoretically already protecting the sacred space within the park boundaries, or sitting by while others reap financial gain by mining inside their sacred spaces. The "moral codes" or taboos associated with the sacred sites Walsh clarifies, "while appearing quite rigid when systematized in discourse, are in fact highly flexible in how they can be interpreted and applied by those who claim the authority to do so." The idea of who holds the authority to interpret local moral codes, and what decisions are made in light of this authority, is central. In the following case study, I will return to this idea of authority to look at what choices are made by local leaders and in what context they make such choices.

\section{2) Community management and mining camps: the case of Soabiby}

In the southwest of Madagascar, over a thousand kilometers south of Ambondromifehy is a village called Soabiby. Soabiby is adjacent to a "community-managed" protected area that was set up in the late 1990 s by a non-governmental organization with consultation and some involvement of local people. Many resource uses are deemed legal within the confines of the protected area, however commercial logging and gemstone mining are considered illegal. All decision-making, monitoring, and certain elements of the enforcement process are theoretically conducted by the communities living adjacent to the protected area. Interestingly, with the arrival of gemstone mining to the area Soabiby residents were able not only to keep migrant miners out of their fields, but also out of large parts of the adjacent community-managed protected area.

Soabiby is located on the banks of the Onilahy, a river that fluctuates seasonally from a thin stream meandering through ridges of sand to a torrent of water that erodes away large swaths of the riverbank. The Onilahy, and the wetland areas adjacent to its banks, are some of the most species-rich areas in southwestern Madagascar(Frontier 2003). In 1998 the Onilahy river valley was identified by WWF as a conservation priority (WWF 2005) (SAGE 2001; WWF 2007). Part of a gallery forest and some portions of the spiny forest located adjacent to a tributary of the Onilahy are considered sacred by the local population. This tributary is known for its series of picturesque waterfalls and clean clear pools of water. Villagers in the region assert that cutting trees from the area adjacent to these cascades and bathing in the lowest sacred pool of water is taboo. WWF saw that this small sacred area functioned essentially as a protected area, and included it in a larger CBNRM project officially inaugurated in 1999, spanning along both sides of the Onilahy river called "Amoron'I Onilahy" (WWF 2005). People in the few villages neighboring this forested area explained that the tributary and surrounding forests are protected largely by the ancestors themselves via spiritual sanctions on those who transgress the rules pertaining to the sacred site. The CBNRM area contained the sacred waterfalls and its forest surrounding in addition to a much larger area which stretched upland of the waterfalls and outward a few dozen kilometers from each side of the tributary. Although the CBNRM area was enlarged from the original taboo forest, villagers interviewed did not seem troubled about 
the expansion of a protected area to their communal land. Instead, most were proud of their state-recognized community-managed area.

Walking in the woods around Soabiby along a dirt road near the falls, one can see no clear demarcation of where the community managed forest boundaries were located. Unlike Ankarana, the protected area adjacent to Soabiby did not have tall stone cairns and bold-printed signs marking "Taboo Forest" (ala fady) around the protected area's edge. Instead the border seamlessly blended into the area where resource use was permitted. Whether this was intentional or not, this invisible boundary deemphasized the resources contained within the area itself. It was perhaps the very imperceptibility of the boundary that allowed greater attention to be placed on the community's designation of and relation to the area, instead of a visible and seemingly arbitrary boundary marker.

In July 2005, approximately eight months after the first sapphires had been discovered, Soabiby had grown from approximately 280 villagers to over 5,000; this small farming and fishing village exploded into a bustling center of commerce with an attached mining camp. On a second visit in February of 2006, the mining population had grown further to approximately 10,000-18,000 people spread within a small region around Soabiby and a village across the river, Marovaky. Miners would regularly go back and forth between each side of the river, working for a few weeks in one area and then picking up and switching camp to a new area. Soabiby was distinct from other mining sites visited because of the level of excitement and optimism as well as the desperation with which people mined. Activity ran at a frenzied pace night and day. The area was full of energy and noise: people selling clothes, suitcases, and shoes in makeshift stalls; women walking around selling simple meals of boiled manioc or peeled mangoes; vendors offering beer and rum; stereos blasting Malagasy music and televisions blaring music videos and kung fu movies into the night. There was a constant 'plink plink' of miners chipping away at rock and dirt in attempts to unearth the valuable sapphires (Figure 3, 4). During my first visit to the site, trading and selling took place primarily on riverbanks where people were sieving through large rice sacks gouny full of pebbly dirt. A little over a year later, stands and other trading structures had been built slightly upland from the river. No foreigners were living in Soabiby, and thus did not act as small mining team organizers. Nor did they trade directly with miners - foreign-owned gemstone buying/trading companies were represented in Soabiby through Malagasy middlemen who often donned shirts with emblems and names of these companies.

\section{Extracting gems and extracting rents}

The layout of Soabiby differed markedly from that of Ambondromifehy. The houses of the population living in the area prior to the arrival of gemstone mining were clustered near the edge of a steep embankment leading down to the banks of the river. A few houses in the middle of the village were made of cement but for the most part hardwood from the forest was used, with dirt floors covered with tarps or woven mats. When the migrant miners first arrived, they were not allowed to stay in the village unless they were direct kin to a villager (there were a handful of these miners from neighboring villages). The vast majority of the migrant miners were from other parts of the island, some had come from as far north as Ambondromifehy, over $1,500 \mathrm{~km}$ by road. These migrant miners were initially forced to stay in the flood zone of the Onilahy, but later they were permitted to construct houses up on the banks and on the outskirts of the established village. Although there were many areas available to construct houses, miners were only allowed to build houses on the already deforested land to the North of the village. The spatial containment of the migrant mining camp in Soabiby was notable compared to Ambondromifehy.

The sacred waterfalls and the CBNRM forest were located directly south of the village. When the village president (a younger man but recognized as part of the tompontanana), was asked why miners built their houses only to the North of Soabiby, he answered the question with a question. "Where else [would they] build houses?" he said. ${ }^{6}$ When pressed for an answer to why the miner's didn't just build on the east side of the village, he laughed and replied "It is not theirs." ${ }^{7}$ Although these questions seemed inane to him, it was perplexing why miners would follow the rules and customs of local authority in Soabiby and not in Ambondromifehy.

During a visit to one of the more productive areas adjacent to Soabiby where sapphires are frequently found, I saw a narrow path meandered between open deep pits, big piles of rocks and sand, and pulleysystems, and house construction around tree stumps cut for firewood. This path was hot, very exposed with very little tree cover, but abruptly become cool as it passed under a dense canopy of trees, in the middle of which there were two large tombs. A hundred meters further, the path emerged from the forested area to another open area pitted with mining holes and hundreds of workers. The total area around these tombs was at least $1 \mathrm{~km}^{2}$, yet intense mining activity had occurred only on the edges of this area. When people were

\footnotetext{
${ }_{7}^{6}$ Aia avao manamboatsy?

${ }^{7}$ Tsy an-drozy io
} 
asked why nobody dug in that patch of forest, numerous miners explained that it's fady ("taboo"). Again, the contrast with Ambondromifehy, where miners dug in caves in which the village's ancestors were buried, was striking.

In a conversation one evening with two olo be (the southern version of tompontanana), I asked why miners dug in certain areas and not others, one replied "We're the land owners. When the land was broken and there were sapphires inside, the landowners went alone to mark the boundaries." The other olo be continued explaining that "Each [mining area] had an owner, for example [drawing in the dirt] this one would be mine, and this one would be his/hers"8 (Soabiby village elder, personal communication, June 14, 2005). The breadth and depth to which Soabiby villagers controlled the land, resources, and mining efforts in the area became clearer. Soabiby had a system of payment, compensation and commission with which miners actually complied. Just the mere presence of a monetary transaction connected to access in the context of such an illicit and ostensibly chaotic industry was remarkable. When gems were first found in the area and miners started arriving, the olo be had not yet devised a system in which to divide the land and extract rents, yet according to one of the olo be, within the first three months a committee (komite) held several meetings (kabary) to work out a system of collective and individual rents.

In Soabiby, the komite members who initiated these meetings to divide the community's land were also lead members of the WWF community conservation committee. The fact that this community organization called itself a "komite" is interesting given that it is a word appropriated from French. "Komite" is rarely used outside the context of conservation and development projects, thus its use helps highlight the probable influence of the CBNRM strategy on how Soabiby village leaders organized to extract rents from gemstone miners. The komite divided all the forested and uncultivated commons area land located around the village (except for directly South of the village where the waterfalls were located) among each extended household of the pre-mining population. The land was divided initially into 12 parts in association with the main 12 family lines in the village, but later changed into a system where each mining hole dug was "given" to a Soabiby villager. Even small children who were part of the pre-mining Soabiby population were assigned holes, and if gems were found from a particular hole, the villager had the right to $10 \%$ commission. In the case of young children, older family members would oversee gems extracted from the hole. Additionally, migrant miners paid rent for a spot in which they dug deep holes. A common fee was approximately 2,000 Ariary (US\$1) per hole per week, but some miners negotiated larger commission on stones discovered for a cheaper flat-rate rent.

Tracking big gems was fairly easy given that bags of dirt are washed at the river and many people, including "team bosses," land and "hole owners" (or their family members), and locally hired armed security surveyed the washing. Each time a sizeable gemstone was uncovered in the washing stage of extraction, people celebrated on the banks of the river either by banging a shovel against a sieve (which gives off a loud but muted metallic sound) or if the team was well equipped, one would shoot a gun into the air near the washing site. Several people told me that it serves both to keep the miners' morale up (manambony morale), and to signal for buyers that a new large gem is on the market. Taking commission from these large gems was fairly easily according to the village president of Soabiby, but the enormous flow of small and medium sized stones were harder to trace, and rumors of lying and avoidance were rampant.

Returning again the idea of moral authority, the case of Soabiby presents an interesting contrast to that of Ambondromifehy. For example, the moral codes that were associated with the forest surrounding Soabiby prior to the arrival of gemstone mining dramatically shifted from communally accessed area to privatized parcels. Social norms concerning Soabiby's forested land had previously prevented an individual from taking more than a reasonable share of commonly held resources such as firewood, bush meat, and wild tubers. The private property model, advanced by the Komite members in Soabiby, changed that norm. Privatization, purportedly helping to facilitate rent extraction from the gemstone mining activity, became morally acceptable. This private property system was even accepted by those who had not yet gained anything from the arrangement. I asked three owners of "unproductive" plots their opinion. As of yet, no mining activity had occurred and no interest had been taken in their land (unproductive land). To my surprise, all three answered that they agreed (nanaiky) and had no problem (tsisy olana) with the arrangement. One middle-age man explained that gems can be found anywhere (naiaia) and that his plot might be mined next. The other two, an elder woman and a young man, explained that splitting up the land was good because it meant that each person relies on his/her destiny (njara). The elder woman explained that it simply wasn't her destiny to have sapphires in her land, and then added that she trusts in God.

However, other moral codes did not shift with the arrival of gemstone mining. The forested and untouched tombstones located in the middle of large swathes of denuded forest in the mining sites, indicated that the taboo of digging around or under tombs remained the same and was respected despite the social and

\footnotetext{
${ }^{8}$ Olobe ay. Tamin'ny vaky tany nisy safira iny, olobe avo ro nande namariparitse. Samby mana ty tompone, hoe toy ty ahy, toy ty ie.
} 
ecological upheaval brought by gemstone mining. What was deemed acceptable and furthermore what was deemed possible varied greatly between Ambondromifehy and Soabiby. The decisions made in Soabiby stem in part from what was imagined possible by village leaders as well as their ability to self-organize quickly and enforce their claims to authority in the area. The komite, previously established with the strong encouragement of conservation organizations working in the area, was an important factor. Committee members had been meeting on a semi-regular basis (multiple times a year) with WWF agents and neighboring village committee members several years before the arrival of gemstone mining. Village members had come to meetings theoretically as resource managers. Thus, the socio-political organization of local people as resource managers helped bolster their claims to authority that migrant miners subsequently respected.

\section{3) Exploring alternative explanations}

The cases outlined above are focused on what I consider to be the dominant drivers of difference in the two villages. Here I highlight other possible factors because while I have favored a particular argument based on the evidence I found in interviews and observation in each research site, the information I received and my perspective is and will always be partial. Many similarities exist between the two villages that lend these cases to comparison. Ambondromifehy and Soabiby are both villages that existed prior to the establishment of the protected area in each region. Similarly, both were primarily farming communities before the rapid influx of hundreds and then thousands of miners. But while both are located fairly close to major cities in Madagascar, Soabiby is located on a secondary road and is difficult to access compared to Ambondromifehy which has a paved road. The difference in accessibility may have had an important influence on who historically settled both of these villages. While both were established approximately 2-3 generations ago, the village founders' relationship to the land prior to the establishment of the village was not explored in this research. Andrew Walsh, an anthropologist who has worked for many decades in the region of Ambondromifehy, questions whether a village with much deeper historical ties to the region that is located on the other side of Ankarana's protected area, a day walk from the paved road, would have been more demanding than Ambondromifehy residents on the migrant miners.

Additionally, the ability to arrive and then leave the mining site in the same day may have had an important influence on what Soabiby or Ambondromifehy villagers deemed possible. For example, most people who came to Soabiby ended up staying at least one night, thus people slept with guns by their side and the only military presence consisted of those hired as personal bodyguards. The reach of regional or national law, literally the movement of protected area agents and/or state-hired military, was significantly aided by the paved road to Ambondromifehy. One could visit Ambondromifehy for several hours in a day and then return to the relative safety of a large city or town located far away. Its added accessibility to the standard representatives of authority (police, park guards, military) may have contributed to undermining the authority of its residents.

The key differences outlined here, amongst possible others, may have had important explanatory power concerning the outcomes observed in Ambondromifehy and Soabiby, and should be included in future research.

\section{Conclusion}

The discourse and practices within conservation schemes can influence the ways in which people conceive and act upon their legitimacy as resource owners and managers. Although some commonalities were highlighted between the sites, the cases outlined in this article are examples of how a "particular set of social relations...interact at a particular location" (Massey 1994). Both villages have distinctive ecological, economic and cultural dynamics. Arguing that there is a unambiguous correlation between protected area management and claims to property is not the intention of this article. Instead I investigated the particular circumstances under which a CBNRM project may have influenced a community's drive or ability to benefit from resource use in their area, and more particularly what elements of CBNRM might have helped this work. In Soabiby, the komite's ability to organize and delegate tenure over a dig site to the original tenants of the land in order to capture benefits (e.g. rents and commission) and to decrease cultural costs (e.g. protecting sacred areas and tombs), stemmed in part from the way in which they understood and acted upon their roles as resource managers. This process was deeply related to the community-based natural resource management strategy occurring in the area.

Informed by the concept of governmentality, the study shows how environmental governance regimes shape not only an individual's actions, but also collective action. The motivations and calculations advanced by the state-managed as well as community-managed conservation projects, both saturated with national and international agendas, were taken up and re-interpreted in interesting and different ways by the communities.

Although biodiversity conservation of the larger CBNRM area around Soabiby was arguably not achieved given the continued cutting of the forest by miners (both migrant and komite members), the smaller 
taboo places were not exploited (the forest directly adjacent to the set of lakes and waterfalls). Similarly, although "local" people participated in the mining efforts in the CBNRM area, they were also able to selforganize and reap extra benefit from mining. However, when a representative from a conservation agent working in the area was asked in 2005 whether CBNRM was an effective conservation strategy in the zone around Soabiby, he responded that "it did not work" because "even committee members have engaged in gemstone mining in the area and deforestation as a result of gemstone mining continues" (personal communication, October 3, 2005). This conservation worker failed to see the ways in which certain tracts of the forest were "conserved" and the way in which certain locals were able to assert control over the resources in the area. The worker's focus on only conservation outcomes means that he did not see some of the positive elements CBNRM contributed to the Soabiby area.

Future research could also include investigating how widespread this type of phenomenon is in different CBNRM sites, with and without "sacred" areas. Deepening our understanding of the ways in which collective claims to resources operate in and around different types of protected areas could explain how conservation ideology affects people's perceived authority, especially in areas with heavy resource extraction.

In Ambondromifehy, the "jackpot effect" was magnified by current state-management practices, magnifying colonial history in the minds of miners. How and why protected area boundaries were drawn and defended remain important to the way in which people perceive and interact with these boundaries today. While CBNRM in Soabiby was conceived as a biodiversity conservation scheme at the national level, at the local level CBNRM was represented by the governmental and non-governmental representatives helping to implement CBNRM as a project aimed to empower and benefit local populations. This local discourse was later mobilized by Soabiby villagers to control the gemstone mining population in the area. While CBNRM may aid conservation, this was not the motivation of the villagers of Soabiby. They placed greater importance in protecting their sacred sites, asserting their authority, and profiting from the land they believed was rightfully theirs. Despite the failure of CBNRM in many cases to truly empower locals, devolve ownership, and protect natural resources, the processes and discourse associated with CBNRM may, as in the case of Soabiby, influence the way in which a community organizes itself to control and benefit from local resource extraction. 


\section{References}

Adams, J. S., and T. O. McShane. 1992. The myth of wild Africa: conservation without illusion. Berkeley: University of California Press.

Adams, W.M., and D. Hulme. 2001. If community conservation is the answer in Africa, what is the question? Oryx 35 (3): 193-200.

Agrawal, A., C. Gibson. 1999. Enchantment and disenchantment: the role of community in natural resource conservation. World Development 27 (6): 629-650.

Agrawal, A., C. Gibson, eds. 2001. Communities and the environment: ethnicity, gender, and the state in community-based conservation. New Brunswick: Rutgers University Press.

Agrawal, A. 2005. Environmentality: technologies of government and the making of subjects. Durham: Duke University Press.

Baland, J., J-P. Platteau. 1996. Halting degradation of natural resources: is there a role for the rural communities? Oxford: Claredon Press.

Borrini-Feyerabend, G. C.B. Tarnowski. 2005. Participatory democracy in natural resource management: a "Columbus’s egg"? In J.P. Brosius, A.L. Tsing, and C. Zerner (eds.) Communities and conservation: histories and policitcs of community-based natural resource management. Oxford: Alta Mira Press.

Brockington, D. 2002. Fortress conservation: the preservation of Mkomazi game reserve Tanzania. Boomington: Indiana University Press.

Brockington, D., R. Duffy, J. Igoe. 2008. Nature unbound: conservation, capitalism and the future of protected areas. Sterling: Earthscan.

Brosius, P., A.L. Tsing, C. Zerner. 2005. Communities and conservation: histories and politics of community-based natural resource management. Oxford: AltaMira Press.

Brown, M. 2002. A history of Madagascar. Princeton: Markus Wiener.

Burchell, G., P. Miller, C. Gordon. 1991. The Foucault effect: studies in governmentality. With two lectures by and an interview with Michael Foucault. Chicago: University of Chicago Press.

Campbell, L. 2002. Conservation narratives in Costa Rica: conflict and co-existence. Development and Change 33 (1): 29-56.

Campbell, L. and A. Vainio-Matila. 2003. Participatory development and community-based conservation: opportunities missed for lessons learned? Human Ecology 31 (3): 417-437.

Cardiff, S., A. Andriamanalina. 2007. Contested spatial coincidence of conservation and mining efforts in Madagascar. Madagascar Conservation and Development 2 (1): 28-34.

Code Minier. 2005. Loi $n^{\circ} 2005$ - 021. Repoblikan'I Madagasikara.

Cooper, F. 1998. Modernizing bureaucrats, backwards Africans, and the development concept. In F. Cooper and R. Packard (eds.). International development and the social sciences. Berkeley: University of California Press. 64-92.

Corson, C. 2011a. From rhetoric to practice: how high-profile politics impeded community consultation in Madagascar's new protected areas. Society and Natural Resources 25 (4): 336-351.

Corson, C. 2011b. Territorialization, enclosure and neoliberalism: non-state influence in struggles over Madagascar's forests. Journal of Peasant Studies 38 (4): 703-726.

Desjeux, D. 1979. La question agraires à Madagascar, administration et paysannat de 1895 à nos jours. Paris: Edition l'Harmattan.

Dressler, W., B. Büscher, M. Schoon, D. Brockington, T. Hayes, C.A. Kull, J. McCarthy, K. Shrestha. 2010. From hope to crisis and back again? a critical history of the global CBNRM narrative. Environmental Conservation 37 (01): 5-15.

Duffy, R. 2007. Gemstone mining in Madagascar: transnational networks, criminalization and global integration. Journal of Modern African Studies 45 (2): 185-206.

Durbin, J. 2006. Madagascar's new system of protected areas - implementing the 'Durban Vision' Conservation International Summary 3.

Economist. 2005. Getting stoned: Madagascar must try to reap more of a benefit from its plentiful gemstones. The Economist July 28: 42.

Fanon, F. 1963. The wretched of the earth. New York: Grove Press.

Fortmann, L., C. Antinori, N. Nabane. 1997. Fruits of their labor: gender, property rights, and tree planting in two Zimbabwe villages. Rural Sociology 63 (3): 295-314.

Fortmann, L. and E. Roe. 1993. On really existing communities - organic or otherwise. Telos 95: 139-146.

Fritz-Vietta, N., B. Ferguson, S. Stoll-Kleemann, and J. U. Ganzhorn. 2011. Conservation in a biodiversity hotspot: insights from cultural and community perspectives in Madagascar. In F.E. Zachos and J.C. Habel (eds.) Biodiversity hotspots: distribution and protection of conservation priority areas. Heidelberg: Springer. 209-233.

Frontier. 2003. The proposed Parc Regional de Belomotse: biodiversity survey and conservation evaluation. United Kingdom \& Madagascar: Frontier: Society for Environmental Exploration; University of Toliara. 
Getz, W., L. Fortmann, D. Cumming, J. du Toit, J. Hilty, R. Martin, M. Murphree, N. Owen-Smith, A. Starfield, and M. Westphal. 1999. Sustaining natural and human capital: villagers and scientists. Science 283 (5409): 1855-1856.

Gezon, L. 1997. Institutional structure and the effectiveness of integrated conservation and development projects: case study from Madagascar. Human Organization 56 (4): 462-470.

Gezon, L. 2006. Global visions, local landscapes: a political ecology of conservation, conflict, and control in northern Madagascar. Plymouth: AltaMira Press.

Goodman, S. and J. Benstead, (eds.) 2003. The natural history of Madagascar. Chicago: University of Chicago Press.

Gouvernement Général de Madagascar et Dépendances, MG. 1937. Arrêté Numéro 6376 Conservation des réserves naturelle. Direction des Domaines de la Propriété Foncière et du Cadastre.

Gouvernement Général de Madagascar et Dépendances, MG. 1937. Réserve indigène Arrêté Numéro 66555 du 4-11-1937, Contrôle Financier. Direction des Domaines de la Propriété Foncière et du Cadastre.

Hanson, P. 2007. Governmentality, language ideology, and the production of needs in Malagasy conservation and development. Cultural Anthropology 22 (2): 244-284.

Hart, G. 2002. Disabling globalization: places of power in post-apartheid South Africa. Berkeley: University of California Press.

Jarosz, L. 1993. Defining and explaining tropical deforestation: shifting cultivation and population growth in colonial Madagascar (1896-1940). Economic Geography 69 (4): 366-379.

Kremen, C., A. Cameron, A. Moilanen, S. J. Phillips, C. D. Thomas, H. Beentje, J. Dransfield, B. L. Fisher, F. Glaw, T. C. Good, G. J. Harper, R. J. Hijmans, D. C. Lees, E. Louis, R. A. Nussbaum, C. J. Raxworthy, A. Razafimpahanana, G. E. Schatz, M. Vences, D. R. Vieites, P. C. Wright, and M. L. Zjhra. 2008. Aligning conservation priorities across taxa in Madagascar with high-resolution planning tools. Science 320 (5873): 222-226.

Kull, C.A. 1996. Evolution of conservation efforts in Madagascar. International Environmental Affairs 8 (1): 50-86.

Kull, C.A. 2002. Empowering pyromaniacs in Madagascar: ideology and legitimacy in community-based natural resource management. Development and Change 33 (1): 57-78.

Kull, C.A. 2004. Isle of fire: the political ecology of landscape burning in Madagascar. Chicago: University of Chicago Press.

Leach, M., R. Mearns, I. Scoones. 1999. Environmental entitlements: dynamics and institutions in community-based natural resource management. World Development 27 (2): 225-247.

Li, T.M. 2002. Engaging simplifications: community-based resource management, market processes and state agendas in upland southeast Asia. World Development 30 (2): 265-283.

Madzudzo, E., J. HaBarad, F. Matose. 2006. Outcomes of community engagement in community-based natural resource management programmes. Programme for Land and Agrarian Studies Policy Brief 22 (December): 1-6.

Massey, D. 1994. Space, place and gender. Minneapolis: University of Minnesota Press.

Messer, K. 2010. Protecting endangered species: when are shoot-on-site policies the only viable option to stop poaching? Ecological Economics 69: 2334-2340.

Murphree, M.W. 1993. Communities as resource management institutions. Gatekeeper Series No. 36. London: International Institute for Environment and Development.

Murphree, M.W. 2009. The strategic pillars of communal natural resource management: benefit, empowerment and conservation. Biodiversity Conservation 18: 2551-2562.

Mutibwa, P. 1974. Madagascar and the Europeans: Madagascar's foreign relations, 1861-1895. London: Longman.

Myers, N., R.A. Mittermeier, C.G. Mittermeier, G. da Fonseca, J. Kent. 2000. Biodiversity hotspots for conservation priorities. Nature 403 (February): 854-858.

Norris, S. 2006. Madagascar defiant. BioScience 56 (12): 960-965.

Peluso, N.L. 1996. Fruit trees and family trees in an anthropogenic forest: ethics of access, property zones, and environmental change in Indonesia. Comparative Studies in Society and History 38 (3): 510-548.

Pollini, J. 2011. The difficult reconciliation of conservation and development objectives: the case of the Malagasy environmental action plan. Human Organization 70 (1): 74-87.

Pollini, J, J.P. Lassoie. 2011. Trapping farmer communities within global environmental regimes: the case of the GELOSE legislation in Madagascar. Society and Natural Resources 24 (8): 814-830.

Rakotoson, L., K. Tanner. 2006. Community-based governance of coastal zone and marine resources in Madagascar. Ocean and Coastal Management 49: 955-872.

REBIOMA. 2012. Atlas numerique du système des aires protegeés de Madagascar. atlas.rebioma.net [Accessed July 2 2012].

Ribot, J. 1999. Decentralization and participation in Sahelian forestry: legal instruments of politicaladministrative control. Africa 69 (1): 23-65.

SAGE. 2001. Le sous-programme autour de la fôret des Sept Lacs, rapport. Toliara: Service D’Appui Pour la Gestion de L’Environnement (SAGE). 
Shrader-Frechette, K., E. McCoy. 1995. Natural landscapes, natural communities, and natural ecosystems. Forest and Conservation History 39: 138-142.

Sivaramakrishnan, K. 2000. Crafting the public sphere in the forests of west Bengal: democracy, development, and political action. American Ethnologist 27 (2): 431-461.

Sodikoff, G. 2005. Forced and forest labor regimes in colonial Madagascar, 1926-1936. Ethnohistory 53 (2): 407-435.

Sodikoff, G. 2007. An exceptional strike: a micro-history of 'people versus park' in Madagascar. Journal of Political Ecology 14: 10-33.

Sodikoff, G. 2009. The low-wage conservationist: biodiversity and perversities of value in Madagascar. American Anthropologist 111 (4): 443-455.

Terborgh, J. 2000. The fate of tropical forests: a matter of stewardship. Conservation Biology 14 (5): 13581361.

Thompson, V., R. Adloff. 1965. The Malagasy Republic: Madagascar today. Stanford: Stanford University Press.

Tsing, A.L. 1999. Becoming a tribal elder, and other green development fantasies. In T.M. Li (ed.) Transforming the Indonesian uplands: marginality, power and production. Amsterdam: Harwood Academic Publishers.

Walsh, A. 2002. Responsibility, taboos and 'the freedom to do otherwise' in Ankarna, northern Madagascar Journal of the Royal Anthropological Institute 8: 451-458.

Walsh, A. 2003. "Hot money" and daring consumption in a northern Malagasy sapphire-mining town. American Ethnologist 30 (2): 290-305.

Walsh, A. 2004. In the wake of things: speculation in and about sapphires in northern Madagascar. American Anthropologist 106 (2): 225-237.

Walsh, A. 2005. The obvious aspects of ecological underprivilege in Ankarana, northern Madagascar. American Anthropologist 107 (4): 654-665.

Western, D., R. Wright, and S. Strum (eds.) 1994. Natural connections: perspectives in community-based conservation. Covelo: Island Press.

WWF. 2007. Community management reinforcement for a new protected area in Amoron'I Onliahy. http://www.panda.org/about_wwf/where_we_work/africa/where/madagascar [Accessed November 25 2010].

\begin{abstract}
Conflict over property and resource rights is a common product of the convergence of biodiversity conservation and natural resource extraction and is especially pronounced in resource rich developing countries. Madagascar, a country well known for its unique and threatened biodiversity as well as its wealth of mineral resources is under great pressure to reconcile the conflict between these two treasures. This article, utilizing research conducted from 2004-2008, explores how resource claims are exercised, by whom, and by what means in two artisanal gemstone mining sites in Madagascar. It argues that the practices and discourses associated with conservation intervention have influenced both the way in which people understand as well as act upon their property rights. The alienation and dispossession accompanying a fortress modeled state-managed protected area is contrasted with a decentralized self-governing communitymanaged model and are posited as key drivers of observed differences in people's claims to resources in two gemstone mining sites. The research shows that community-managed conservation had an unexpected influence on a community's assertion of greater authority over gem resources.
\end{abstract}

Key words: Community management, conservation, mining, Madagascar, governance 


\section{Résumé}

Conflit concernant les droits de propriété et des ressources naturelles se passe souvent avec la convergence de la conservation de la biodiversité et l'extraction des ressources naturelles. Ce conflit est particulièrement prononcé dans les pays en voie de développement qui sont riches en ressources naturelles. Madagascar, un pays bien connu pour sa biodiversité unique et menacées ainsi que la richesse de ses ressources minérales est sous forte pression pour résoudre le conflit entre ces deux trésors. Cet article, en utilisant des recherches effectué en 2004-2008, explore comment les demandes de ressources sont exercées, par qui, et par quels moyens dans deux sites ou se trouvent l'extraction artisanaux des pierres précieuses à Madagascar. Cet article soutient que les pratiques et les discours liés avec conservation influencent à la fois la façon dont les gens à comprendre ainsi que la loi sur leurs droits de propriété. L'aliénation et la dépossession qui accompagne une modèle forteresse de conservation gérée par l'état est en contraste avec une modèle de conservation décentralisée avec l'autonomie gouvernementale géré par la communauté sont posés comme les principaux engins de différences observées concernant les revendications des populations riveraines aux ressources naturelle dans deux sites d'extraction des pierres précieuses. La recherche montre que la gestion communautaire de conservation a eu une influence inattendue sur l'affirmation de plus grande autorité sur les ressources précieuses pour la communauté riveraine.

Mots clés: gestion communautaire, conservation, l'exploitation minière, Madagascar, gouvernance

\section{Resumen}

La aparición de conflictos motivados por la tensión entre pobreza y derechos sobre recursos es un producto común de la convergencia entre conservación de la biodiversidad y extracción de recursos naturales y es especialmente pronunciada en países en vías de desarrollo con abundantes recursos naturales. Madagascar, un país bien conocido tanto por su biodiversidad única y en peligro, como por la riqueza de sus recursos minerales afronta una gran presión para reconciliar el conflicto entre estos dos tesoros. Este artículo, haciendo usa de investigación llevada a cabo entre 2004 y 2008, explora la forma en que se ejercitan las reclamaciones de derechos, por quién y cómo en dos áreas de minería artesanal de gemas en Madagascar. Se afirma que las prácticas y los discursos asociados con el deseo de conservación han influido tanto en la forma en que la gente entiende sus derechos de propiedad como en la forma en que actúa respecto a ellos. La alienación y la desposesión que acompañan el modelo de áreas al estilo de fortalezas protegidas y administradas por el estado se compara con un modelo descentralizado, administrado por la comunidad y autogobernado; ambos modelos muestran ser raíz fundamental de las diferencias en las reclamaciones de la gente a recursos en dos lugares dedicados a la minería de gemas. La investigación demuestra que la conservación administrada por la comunidad tuvo una influencia inesperada en una aserción de mayor autoridad por parte de la comunidad sobre los recursos de gemas.

Palabras clave: Administración comunitaria, conservación, minería, Madagascar, gobernabilidad. 